Volume 11

Issue 3 Global Approaches to Atrocity

Prevention: Theory, Practice, and the State of

Article 18 the Field

\title{
Book Review: The Failures of Ethics: Confronting the Holocaust, Genocide, and Other Mass Atrocities
}

James J. Snow 4995784

Loyola University Maryland

Follow this and additional works at: https://digitalcommons.usf.edu/gsp

\section{Recommended Citation}

Snow, James J. 4995784 (2018) "Book Review: The Failures of Ethics: Confronting the Holocaust, Genocide, and Other Mass Atrocities," Genocide Studies and Prevention: An International Journal: Vol. 11: Iss. 3: 141-144.

DOI:

http://doi.org/10.5038/1911-9933.11.3.1500

Available at: https://digitalcommons.usf.edu/gsp/vol11/iss3/18

This Book Review is brought to you for free and open access by the Open Access Journals at Digital Commons @ University of South Florida. It has been accepted for inclusion in Genocide Studies and Prevention: An International Journal by an authorized editor of Digital Commons @ University of South Florida. For more information, please contact digitalcommons@usf.edu. 


\title{
Book Review: The Failures of Ethics: Confronting the Holocaust, Genocide, and Other Mass Atrocities
}

\author{
James J. Snow \\ Loyola University Maryland \\ Baltimore, MD, USA
}

The Failures of Ethics: Confronting the Holocaust, Genocide, and Other Mass Atrocities

John K. Roth

New York, Oxford University Press, 2015

264 Pages; Price: \$39.95 Hardcover

Reviewed by James Snow

Loyola University Maryland

Genocide scholars are of course familiar with the work of John K. Roth who has authored, coauthored, and edited numerous volumes on the Holocaust and other genocides. His most recent book, The Failures of Ethics: Confronting the Holocaust, Genocide, and Other Mass Atrocities, may well be his most insightful work yet. It is a work that deserves a careful reading by all of us in the field of Genocide Studies, irrespective of disciplinary lens.

Perhaps most noteworthy is the fact that he is resolute in confronting the horrors of genocide. He quotes Emmanuel Levinas to the effect that "The Holocaust of the Jewish people under the reign of Hitler...seems to me the paradigm of gratuitous human suffering, in which evil appears in its diabolical horror." ${ }^{1}$ He concludes his chapter on "God's Failures" with a call for "no more theodicy." Roth explores the possibility that in an era of postmodern relativism the Holocaust might well be a "negative absolute." ${ }^{2}$ And following Jean Améry, Roth takes to heart the insight that the Holocaust and other atrocities including rape and torture mark "the destruction of trust in the world." ${ }^{3}$ Yet like Primo Levi and Elie Wiesel-Roth acknowledges a deep debt to Wiesel-Roth refuses to abandon hope. At the conclusion of Part I (of II) Roth writes:

'And yet . . . and yet,' Elie Wiesel has said, 'this is the key expression of my work.' That outlook should also be a key response to the failures of ethics, including God's failures, because life persists, history continues, and they embody so much that is good and precious, so much that must not be abandoned-perhaps even God? - lest failure is compounded to the point of no return. ${ }^{4}$

And Roth certainly strikes a similar albeit cautious message of hopefulness at the end of the entire work. What then, are the failures of ethics that Roth discusses? For as he is right to claim, "if ethics is to be a safeguard against its own failures, then people who try to be ethical have to acknowledge the failures, own them when they should, and protest against them." 5 The first failure he discusses is the problem and process of bystanding. Drawing from Wendy Lower ${ }^{6}$ and Omer Bartov, ${ }^{7}$ among others, Roth draws attention to the scope of the problem-most Germans during the Holocaust were neither perpetrators nor victims - and also problematizes the received understanding of bystanders as entirely passive and without agency. He is surely right in claiming "No single size fits all bystanders, but conditions for inclusion in that category involve knowledge

${ }^{1}$ John K. Roth, The Failures of Ethics: Confronting the Holocaust, Genocide, and Other Mass Atrocities (New York: Oxford University Press, 2015), 99. Roth is quoting Emmanuel Levinas, Entre Nous: On Thinking-of-the-Other, trans. Michael B. Smith and Marsha Harshav (New York: Columbia University Press, 1998), 97.

${ }^{2}$ Roth, The Failures of Ethics, 21.

${ }^{3}$ Ibid., 30.

${ }^{4}$ Ibid., 101. Roth is quoting Elie Wiesel, "Exile and the Human Condition," in Against Silence: The Voice and Vision of Elie Wiesel, ed. Irving Abrahamson (New York: Holocaust Library, 1985), 1:183.

${ }^{5}$ Roth, The Failures of Ethics, 7.

${ }^{6}$ Wendy Lower, Hitler's Furies: German Women in the Nazi Killing Fields (New York: Mariner Books, 2014).

${ }^{7}$ Omar Bartov, ed. The Holocaust: Origins, Implementation, Aftermath (New York: Routledge, 2000). 
and agency." ${ }^{8}$ Many, if not most, of us have the power to in various ways challenge the scope and depravity of genocidal violence.

A second failure is the abandonment of moral absolutes in favour of a postmodern, Nietzschean celebration of the individual and the will to power as the source of value. A related problem is that celebrating the individual as the source of all value risks abandoning our responsibility to and for others. Roth is hesitant to call for the recovery of a religiously grounded moral absolutismsomething embraced by, among others, David Patterson. ${ }^{9}$ Roth seems forced to acknowledge that "ethical outlooks" are social constructs with a history, but even so something like the Holocaust can still serve as a negative absolute; in his view even a socially constructed ethics can still be extremely powerful. ${ }^{10}$

The shortest chapter of the book, "Rape as Torture and the Responsibility to Protect" - a mere fourteen pages - is nevertheless important for its recognition that rape and other forms of torture have an as yet insufficiently understood enduring destructive potential: the ubiquity of rape as a weapon of genocide prompted the Outcome Document of the United Nations World Summit (2005), ${ }^{11}$ along with Resolution $2150 .{ }^{12}$ Roth, among others, remains sceptical about the efficacy of the Responsibility to Protect initiative; he argues that a sense of "urgency and reality" might well require attentive listening to the dead. He suggests that "listening to those 'done to death' by rape/ torture-as-policy in war and genocide, [might] improve the odds that moral motives will bite in the ways we need them to do."13

Additional chapters cover more familiar but nevertheless important topics. An additional chapter calls for a trialogue among Jew, Christians, and Muslims to refocus attention on the proscription of murder, a proscription at the heart of all three religions. He devotes a chapter to "God's failures" as well. Part II, "Resisting Failures," adopts a more personal voice; "The Holocaust's impact on Christian-Jewish Relations" reads more like personal memoir. As a practicing Christian, Roth has spent decades confronting Christian-Jewish relations and how European Jews such as Elie Wiesel both understood and feared Christianity, and how "Christian understandings - better identified as misunderstandings - of Judaism have produced immense suffering and sorrow."14 Strongly influenced by Elie Wiesel-Roth published "Tears and Elie Wiesel"15 in 1972-Roth does not shy away from the claim that but for centuries of Christian anti-Semitism the Holocaust would not have happened. ${ }^{16}$

Roth makes a strong case for the failures of ethics, and there are many. And many of these failures have their origins in philosophy itself. Philosophy is implicated in bystanding and failing to protect; philosophy is similarly implicated in the logic of racism and the collapse of moral absolutism. Reflecting on Kristallnacht and the destruction of the synagogue in the city of Nentershausen, Roth claims: "A decisive failure of ethics, the destruction of the Torah scrolls signified unbounded rejection of Jewish tradition, a 'cleansing' of the Ten Commandments and their injunction against murder." 17 Given the scope and depth of these failures, how does Roth propose, in his words, "resisting these failures?"18

\footnotetext{
${ }^{8}$ Roth, The Failures of Ethics, 15.

${ }^{9}$ David Patterson, Genocide in Jewish Thought (New York: Cambridge University Press, 2012).

${ }^{10}$ Roth, The Failures of Ethics, 22.

11 "Paragraphs 138-139 of the World Summit Outcome Document," International Coalition for the Responsibility to Protect, accessed May 20, 2017), http://responsibilitytoprotect.org/index.php/component/content/article/35-r2pcs-topics/398general-assembly-r2p-excerpt-from-outcome-document.

${ }^{12}$ United Nations, "Resolution 2150," accessed May 20, 2017, http://www.securitycouncilreport.org/atf/cf/\%7B65BFCF9B6D27-4E9C-8CD3-F6E4FF96FF9\%7D/s res 2150.pdf.

${ }^{13}$ Roth, The Failures of Ethics, 37.

${ }^{14}$ Ibid., 107.

${ }^{15}$ John K. Roth, “Tears and Elie Wiesel," Princeton Seminary Bulletin 65, no. 2 (1972): 42-48.

${ }^{16}$ Roth, The Failures of Ethics, $115 \mathrm{ff}$.

${ }^{17}$ Ibid., 74.

${ }^{18}$ Ibid., 103.
} 
As mentioned earlier in this review, Roth proposes reconceptualising the status of bystanding and recognizing that bystanding makes genocides possible. Moreover, bystanding involves some degree of agency and therefore moral culpability. He also advocates giving moral traction to the duty to protect, especially in the case of rape and torture, and deconstructing the concept of race. More provocatively, and in the continuing reverberations of the Holocaust, Roth claims, "Christians have yet to come to terms fully with the Holocaust's implication that Christianity can no longer take itself to be superior to Judaism." This recognition needs to deepen for Christianity to advance, and "such advancement," claims Roth, would require profound changes in Christian thought and practice." 19

A great and still growing body of scholarship is devoted to concerns over how best to define genocide. Lemkin's definition that was adopted as part of The Convention on the Prevention and Punishment of the Crime of Genocide by the United Nations General Assembly (UNGA) in 1948 has been and continues to be contested both as a juridical term and as a scholarly concept. ${ }^{20}$ Roth wades into the definitional issues only briefly but suggests that what is needed is courage and resolve. Roth claims that definitional conundrums aside,

"that genocide refers to a reality that deserves no more victories. Like so much else in human experience, more than half the battle depends on the force of will to say, in spite of imperfect definitions, that the most reliable evidence and straight forward clarity insist that genocide is taking place there and must be stopped, or that genocide is likely to take place here and must be prevented." ${ }^{21}$

Roth's chapter on "the politics of testimony" is especially illuminating for the recognition that genocide testimony, in all its forms, "plunges one into abysmal darkness." 22 Here he quotes Philip Hallie: "You cannot go down into hell with impunity. You must pay an entrance fee, and an exit fee too." ${ }^{23}$ The research of Lawrence Langer ${ }^{24}$ for example, contravenes our platitudes that good will prevail over evil or even that such testimonies can form a coherent narrative to help make sense of things. Victim testimony for Langer gives knowledge that "does not unify, edify, or dignify the lives of former victims." ${ }^{25}$ Yet for Roth, the abyss of the darkness that is revealed in survivor testimony cannot be ignored. Contained in the abyss of darkness are glimmers of hope. Citing Primo Levi's Moments of Reprieve ${ }^{26}$ and the story of Lorenzo Perrone, Roth reminds us that testimonies also provide "reminders of obligations and possibilities that can resist the failures of ethics, even when it may seem hopeless to do so." ${ }^{27}$ In the end, one cannot continue to escape the moral responsibility of resisting the failures of ethics, and find meaning and joy in doing so.

At times I found The Failures of Ethics somewhat frustrating to read owing to the brevity of the arguments as they were cast. But then I was reminded of what Robert Pogue Harrison says of his own book, The Dominion of the Dead. Harrison warns his readers that his book is not a writer's book but a reader's book in that

"its articulation is full of empty spaces for the reader to enter and wander about in. It calls on the interlocutor not only to think along with the author but to establish independent connections,

\footnotetext{
${ }^{19}$ Ibid., 127.

${ }^{20}$ For an overview of problems defining 'genocide' see James Snow, ““'Don't Think But Look:” Using Wittgenstein's Notion of Family Resemblances to Look at Genocide," Genocide Studies and Prevention: An International Journal, no.3, 154-173. http://doi.org/10.5038/1911-9933.9.3.1308.

${ }^{21}$ Roth, The Failures of Ethics, 137.

${ }^{22}$ Ibid., 173.

${ }^{23}$ Ibid. Roth is quoting Philip Hallie, Tales of Good and Evil, Hope and Harm (New York: Harper Collins, 1997), 22.

${ }^{24}$ Lawrence Langer, Holocaust Testimonies: The Ruins of Memory (New Haven: Yale University Press, 1991).

${ }^{25}$ Roth, The Failures of Ethics, 178.

${ }^{26}$ Primo Levi, Moments of Reprieve: A Memoir of Auschwitz, trans. Ruth Feldman (New York: Penguin, 1987).

${ }^{27}$ Roth, The Failures of Ethics, 183.
} 
leap over abysses, pursue his or her own paths of inquiry, bring to bear adventitious considerations, and, through the tracings offered here, discover the topic for him-or herself." 28

Harrison's description of the structure of his own book is also an apt description of Roth's book. Roth will not allow us to read his book as bystanders. Roth has written a reader's book, and that is what the best books are, after all.

${ }^{28}$ Robert Pogue Harrison, The Dominion of the Dead (Chicago: Chicago University Press, 2003), xii. 